\title{
Isolation and Examination of the Host Range of the Pseudomonas aeruginosa Bacteriophages Isolated from Sewage
}

\author{
Najat A. Zaman \\ Department of Biology \\ College of Science \\ Kirkuk University
}

(Received 12 / 4 / 2010 ; Accepted 7 / 6 /2010)

\begin{abstract}
Four pathogenic bacteria isolated from the sewage in this study : Pseudomonas aeruginosa, Escherichia coli, Staphylococcus aureus and Proteus mirabilis. Escherichia coli in addition to Pseudomonas aeruginosa were sensitive to the Pseudomonas aeruginosa bacteriophages that isolated from the sewage .Three other Pseudomonas specieces were tested for the sencitivity to the isolated bacteriophages only Pseudomonas specieces with green and yellow pigmentation on Nutrient agar were sensitive to the isolated phages.
\end{abstract}

Key words: Isolation, Pseudomonas, bacteriophage, sewage.

\section{Pseudumonas aeuroginosa عزل ورلسة مدى المضيف لماثيلت بكتربا المعزولة من ميل المجاري}

\author{
الملغص

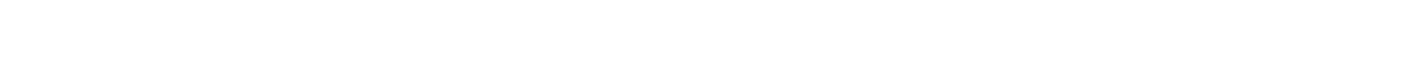

.Proteus mirabilis, Pseudomonas aeruginosa, Escherichia coli, Staphylococcus aureus بكتريا Escherichia coli بالإضافة إلى بكتريا Pseudomonas aeruginosa أظهرت عسلسيتها لعاثيلت بكتريا Pseudomonas aeruginosa المعزولة من نف العينة وكما م درلسة مسلسية ثلاثة ع ـزلات

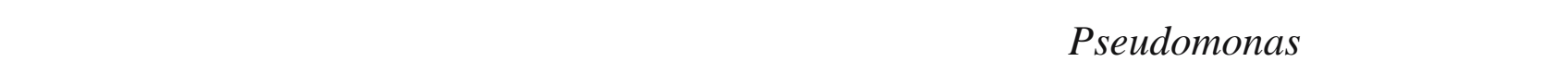
الخضراء والأنواع التي تقرز الألوان الصفراء عند زرعها على وسط المار المغذي Nutrient agar. 